\title{
Autism Diagnosis in the Core Competency Principle: First Contact, Open Access, All Health Problems
}

\section{İlk Temas, Açık Erişim, Tüm Sağlık Sorunları Çekirdek Yeterliği Çerçevesinde Otizm Tanısı}

\author{
Ayşe Şahin**, Cüneyt Ardıç ${ }^{2}$
}

\begin{abstract}
A six-year-old male patient who has a twin healthy brother was admitted to our family medicine clinic with complaints of cough, sputum, and nausea. On physical examination, fever was $36.7^{\circ} \mathrm{C}$, oropharynx was hyperemic, he had tonsillar hypertrophy, left ear discharge and respiratory sounds were natural. The patient was diagnosed with "Acute Upper Respiratory Tract Infection" and treatment was started. During the examination, the patient was agitated and fearful, unable to concentrate, did not make eye contact, did not respond to questions and warnings, and exhibited distinct behavioral differences from his twin, such as shouting and crying, and aggressive features. When his medical history was questioned, he was learned to have born to a 45-year-old father and a 35-year-old mother through in vitro fertilization method on 35 weeks and 4 days, he was 2650 gram. He was breastfed for 8 months, could speak a word around the age of 2, and there was usually a neurodevelopmental process behind his twin. Considering this situation, the patient was referred to the child psychiatry outpatient clinic due to the suspicion of autism. He was evaluated in the child psychiatry outpatient clinic for the first time three years ago, since his speech did not start at the same time with his twin, and he was recommended to come for a followup visit 3 months later with a pre-diagnosis of autism. The patient, who did not come for the control, was diagnosed with "Autism" after the evaluation in our family medicine clinic.
\end{abstract}

Key words: Autism, autism spectrum disorders, family medicine

\section{ÖZET}

Altı yaşında sağlıklı ikiz eşi olan erkek hasta öksürük, balgam ve mide bulantısı şikayetleriyle aile hekimliği polikliniğimize başvurdu. Fizik muayenede ateş $36,7^{\circ} \mathrm{C}$, orofarinks hiperemik, tonsiller hipertrofikti, sol kulakta akıntı mevcuttu, akciğer sesleri doğaldı. Hastaya "Akut Üst Solunum Yolu Enfeksiyonu” tanısı koyularak tedavi başlandı. Muayene süresince hasta ajite ve korkuluydu, dikkatini toplayamıyor, göz teması kurmuyor, sorulara ve uyarılara yanıt vermiyor, bağırma ve ağlamayla birlikte saldırgan özellikler gibi ikizinden belirgin davranışsal farklılıklar sergiliyordu. Özgeçmişi sorgulandığında 45 yaşındaki baba ve 35 yaşındaki anneden in vitro fertilizasyon yöntemiyle 35 hafta 4 günlük 2650 gr doğduğu, 8 ay anne sütü aldığı, 2 yaş civarında tek kelime konuşabildiği, genel olarak nörogelişimsel sürecin ikizinden daha geride olduğu ortaya çıkmıştır. Bu durum dikkate alınarak otizm şüphesi üzerine hasta çocuk psikiyatri polikliniğine yönlendirildi. Yapılan inceleme sonucu üç yıl önce hastamızın konuşmasının ikiziyle aynı dönemde başlamaması üzerine hastamız ilk defa çocuk psikiyatri polikliniğinde değerlendirilmiş, otizm ön tanısıla 3 ay sonra kontrole gelmesi önerilmiş. Önerilen kontrole gelmeyen hasta aile hekimliği polikliniğimizdeki değerlendirme sonucu yönlendirilmesiyle "Otizm" tanısı aldı.

Anahtar kelimeler: Otizm, otizm spectrum bozukluğu, aile hekimliği

Received / Geliş tarihi: 06.01.2021, Accepted / Kabul tarihi: 25.05.2021

${ }^{1}$ Recep Tayyip Erdoğan Üniversitesi Tıp Fakültesi Aile Hekimliği Anabilim Dalı, RİZE (ORCID: 0000-0002-8801-6722)

${ }^{2}$ Recep Tayyip Erdoğan Üniversitesi Tıp Fakültesi Aile Hekimliği Anabilim Dalı, RİZE (ORCID: 0000-0001-8018-9314)

*Address for Correspondence / Yazışma Adresi: Recep Tayyip Erdoğan Üniversitesi Tıp Fakültesi Aile Hekimliği Anabilim Dalı, RİZETÜRKIYE,

E-mail: draysesahinn@gmail.com

Sahin A, Ardic C. Autism Diagnosis in the Core Competency Principle: First Contact, Open Access, All Health Problems. TJFMPC, 2021;15(3): 642-644

DOI: $10.21763 / \mathrm{tjfmpc} .854939$ 


\section{INTRODUCTION}

Autism spectrum disorder (ASD) is a clinical picture characterized by a genetic basis in its etiology, environmental factors increase the risk with epigenetic interactions and affect the connections of neurons, usually beginning in early childhood, marked inadequacy in the socialcommunicative field and limited, repetitive behaviors and interests. ${ }^{1}$

In the report of Center for Disease Control (CDC) published in 2012, the prevalence of ASD was reported to be 1/68 and it is seen 3-4 times more in boys than in girls. The Diagnostic and Statistical Manual of Mental Disorders-5 (DSM-5) classification system discusses the clinical characteristics of ASD in two dimensions as socialcommunicative insufficiency and repetitive ceremonial behaviors. Patients exhibit symptoms of insufficiency in the social-communicative field; it includes problems in social communication, emotional and social interaction, conducting mutual dialogue, non-verbal communication, establishing and conducting human relations. Restricted, repetitive behavioral patterns, interests and signs of behavior are repetitive motor behaviors such as kicking, clapping, shaking, spinning around itself, hand rubbing, repetitive games with non-functional objects, repetitive speech (for example echolalia, saying the same word or sentence over and over) consists of behaviors such as not showing interest in typical toys and games, studying them rather than playing with toys. ${ }^{1}$ Few families suspect this situation in the first year of life, and families usually make their first clinical application with speech delay when their children are 2-3 years old. In school age and adolescence, children who have insight are aware that they are different and therefore, despite their efforts to be with their peers, they are exposed to disdain due to their incompetence and strangeness, which can lead to the development of depressive symptoms and suicidal thoughts and even suicide attempts in $40 \%$ of individuals. Educational treatment, which is the most effective approach in ASD, is applied and pharmacological treatment is added for comorbid psychiatric conditions. ${ }^{1-3}$ Although the majority of children diagnosed with autism had this clinical diagnosis for life, it was observed that children who were diagnosed at an early age and continued intensive educational programs were out of the autism spectrum in the future. ${ }^{4}$

\section{CASE}

A six-year-old male patient who has a twin healthy brother was admitted to our family medicine clinic with complaints of cough, sputum, and nausea. On physical examination, fever was $36.7^{\circ} \mathrm{C}$, oropharynx was hyperemic, he had tonsillar hypertrophy, left ear discharge and respiratory sounds were natural. The patient with height: 120 $\mathrm{cm}$, weight: $27.5 \mathrm{~kg}$, body mass index: $19 \mathrm{~kg} / \mathrm{m}^{2}$ was diagnosed with "Acute Upper Respiratory Tract Infection" and treatment was started. During the examination, the patient was agitated and fearful, unable to concentrate, did not make eye contact, did not respond to questions and warnings, and exhibited distinct behavioral differences from his twin, such as aggressive features accompanied by shouting and crying. When his medical history was questioned, it was leatned that when the patient was born, his mother was 35 years old and his father was 45 years old. He was born with in vitro fertilization method, $2650 \mathrm{~g}$ at 35 weeks and 4 days. He was breastfed for 8 months, took formula in addition to breast milk from birth, and consumed packaged foods frequently after the age of 2 , it was also revealed that the neurodevelopmental process in general was far behind his twin. Although they had gained the toilet habit on time, the patient and his twin were diapered at nights. His twin goes to the nursery, but our patient did not go to the nursery because he did not want it. There was no history of surgery or trauma or any accompanying neurological disease. The parents were not relatives, there was no family history of psychiatric illness. When the patient was 2 years old, he spent 4-5 hours a day on the tablet and the phone also during eating. He spent most of the day watching television, especially paying attention to advertisements. Considering all the conditions, the patient was referred to the child psychiatry outpatient clinic upon the suspicion of autism. As a result of the examination, our patient was evaluated in the child psychiatry outpatient clinic for the first time three years ago, since his speech did not start at the same time with his twin, and he was recommended to come for a follow-up visit 3 months later with a pre-diagnosis of autism. Family physicians, who are the first contact point with patients, should be aware of the diagnosis of childhood autism, whose early diagnosis is very important for the prognosis of the disease, and complete biopsychosocial examination, which is a requirement of intact child follow-up examination. In addition, correct communication with the patient is one of the effective ways to gain trust. Since the father of our patient was a hospital staff, he was found that the comprehensive and continuous point of view of the family medicine discipline was avoided and that our patient communicated with a physician with a request for symptomatic treatment from other specialties and he did not come to suggested psychiatric control. Three years later, the patient who applied to us was able to go to the child psychiatry outpatient clinic with effective communication as we gained the patient's trust, and he was diagnosed with childhood autism. 


\section{DISCUSSION}

Patient-centered clinical management is one of the main features that make family medicine a discipline. In the definition made by the World Health Organization in 1948, "Health is not only the absence of disease and disability; it is a state of physical, mental and social well-being. ${ }^{5}$ For this reason, every problem should be handled unconditionally in family medicine units, which are the first contact points of patients. ${ }^{6}$ When the symptoms and signs do not indicate a clearly definable disease process, when the patient's reactions to the disease are exaggerated or unusual, the physician can diagnose the disease more easily by considering the individual as a whole. Our case is a good example of this situation. When the patient who came with upper respiratory tract complaints was evaluated biopsychosocially, it created a suspicion of autism and a diagnosis was made by establishing a good communication with the patient's relative.

Well-communicated patients help the doctor diagnose problems and in sharing information, and they are much more compatible to recommendations. ${ }^{7}$ Although our patient had applied to the child psychiatry outpatient clinic when he was only three years old, his diagnosis was delayed because he did not go for control. Thanks to the collaborative communication established with the family, being directed by our clinic enabled the patient to be diagnosed and increased his compliance with treatment.

Our patient did not receive any medical treatment during the 8-month follow-up after the diagnosis, and received special education 5 days a week and 2 hours a day from the time of diagnosis. Six months after the beginning of the education, he started to recognize letters and numbers and was drawing pictures. It was stated by his instructors that he could start first grade with a normal education program at the same time as his peers. The family states that they noticed the positive change in this process and that they are very happy with this situation.

Since early diagnosis in autism has a very important place in the progression of the disease, family physicians should listen and observe the patient effectively in line with the patient-centered clinical method principle for each patient, and thus create correct pre-diagnoses with the clues obtained. Therefore, although a definitive diagnosis is not made in primary care, a common ground can be established with the patient and a management plan can be made for the disease.

\section{CONCLUSION}

Considering that early behavioral intervention practices as a result of early diagnosis in autism improve daily communication skills, social competence and life skills, expressive and receptive language development, family physicians should carefully evaluate children at an early age.

\section{Conflict of interest}

No potential conflict of interest relevant to this article was reported.

\section{Source of Funding}

None declared.

\section{REFERENCES}

1. Tanıdır C, Mukaddes NM, Otizm Spektrum Bozuklukları. In: PekcanlarAkay A, Ercan ES, editors. Çocuk ve Ergen Ruh Sağlığı ve Hastalıkları. Ankara: Türkiye Çocuk ve Genç Psikiyatrisi Derneği Yayınları;2016. p. 126-49.

2. Mukaddes NM, Tanıdır C. Otizm Spektrum Bozukluklarında Psikiyatrik Komorbidite. Turkiye Klinikleri J Child Psychiatry-Special Topics 2015;1(2):30-42.

3. Matson JL. Determining treatment outcome in early intervention programs for autism spectrum disorders: A critical analysis of measurement issues in learning based interventions. Research in developmental disabilities 2007; 28(2): p. 207- 218.

4. Reichow B, Baron EE, Boyd BA, Hume K. Early intensive behavioral intervention for young children with autism spectrum disorders. In: Cochrane Database of Systematic Reviews [Internet]. Accessed Jan 1, 2021. http://www.ncbi.nlm.nih.gov/pubmed/2307695 6 doi: 10.1002/14651858.CD009260.pub2.

5. World Health Organisation. WHO remains firmly committed to the principles set out in the preamble to the Constitution. https://www.who.int/about/who-weare/constitution. Accessed Jan 1, 2021.

6. Ford S. Patient-centered Medicine, Transforming the Clinical Method (2nd edition). Health Expect. 2004;7(2):181-182. doi:10.1111/j.1369-7625.2004.00270.x.

7. Yarış F. Koruyucu Hekimlikte Klinik Yöntem. Turkiye Klinikleri J Fam Med-Special Topics 2013;4(5):24-8. 